\title{
LADRÕES DE CASACA
}

POPINIGIS, Fabiane. Proletários de casaca: trabalhadores do comércio carioca, 1850-1911. Campinas: Editora Unicamp, 2007.

\section{Carlos Ziller Camenietzki \\ Depto. de História/UFRJ.}

Não resta nenhuma dúvida quanto à importância da interpretação das fontes na pesquisa histórica. Para além da dificuldade própria em defini-las, de examinar textos antigos, de buscar a lógica imediata de sua composição e de enquadrar o documento lido na vida de homens mortos, interpretar o que se lê é um problema maior para os que investigam e escrevem a história.

O recente Proletários de casaca, escrito por Fabiane Popinigis e publicado pela Editora da Unicamp, é um bom exemplo de um modo de interpretar fontes históricas. A autora investigou vasta documentação sobre os trabalhadores da cidade do Rio de Janeiro dedicados ao comércio, seus conflitos trabalhistas, suas organizações e seus afazeres na cultura urbana carioca na passagem do século XIX ao XX. Bom assunto, boa pesquisa, bom livro.

A exposição começa buscando situar os trabalhadores do setor de serviços na época escolhida e, em seguida, lemos sobre suas organizações sindicais e políticas, suas reivindicações e a forma de articulação de seus interesses com aqueles de outros agentes da política naquele tempo. Desfilam periódicos, escritores, políticos, pleitos trabalhistas e tensões entre este grupo e os demais trabalhadores da sociedade. Enfim, temos a nítida impressão de que o Rio de Janeiro foi uma cidade como as outras capitais do Ocidente - coisa que ademais vem acompanhando o leitor desde o início da obra, já que abundam inúmeras referências aos trabalhadores no comércio francês na mesma época.

Contudo, ao final, a autora insere um capítulo sobre processos criminais envolvendo os caixeiros. Nesta parte do livro, a boa impressão que o estudo provoca desde o início acaba se esmaecendo um pouco. Não é pequeno conside- 
rar que a análise dos crimes envolvendo os caixeiros deva evidenciar traços da cultura das camadas mais pobres dessa profissão. Esse problema é complexo e envolve a elegante consideração de que o desvio das normas e leis da sociedade pode ser boa porta de entrada para o estudo da vida de gente participante de um grupo social dinâmico. Fabiane Popinigis conhece bem os meandros, e também algumas consequências, dessa opção de análise. Porém, o leitor não está obrigado a conhecer sua estratégia de investigação. E ficamos com o confessável desejo de ver as modalidades de tratamento que a autora dá a este problema.

Ao menos boa parte dos que terão contato com a obra desconhecem inteiramente o fato de que o crime, o desvio, a exceção oferecem um ponto de vista privilegiado para interrogar norma, para identificar aspectos dissimulados daquilo que rege a vida comum das pessoas. De fato, extrair do excepcional o regular, da minoria a maioria, é esforço que não se deve pedir ao leitor. Em geral, o impacto causado pelo contato com a estranheza de um processo criminal de há tempos excita a curiosidade e atrai as atenções. O que se conta acaba mais parecido com a celebração de pequenos conflitos estranhos do que uma estratégia de pensar a cultura. Afinal, a imensa maioria dos caixeiros não se envolvia em brigas e nem se embebedava na rua do Lavradio.

A face conflitiva das relações sociais que se expressa na forma do crime, do delito, da contravenção, é muito singular na cultura de qualquer grupo social, não é o quotidiano de ninguém, nem mesmo daqueles envolvidos nos atos. $\mathrm{O}$ estudioso pode transformar essa singularidade em expressão de processos amplos, observados a sobrevôo, e com isso concluir teses importantes sobre as transformações das sociedades, das classes sociais, da própria luta entre elas. Afinal, Proletários de casaca incide sobre um tempo em que a agitação política das classes subalternas era tratada como crime em diversos países do Ocidente. Para não alongar, basta lembrar da adoção do dia primeiro de maio como data simbólica dos trabalhadores. Mas os crimes que informam esta última parte do trabalho não são tratados como expressão de conflitos significativos de grandes processos. Ao contrário, eles aparecem como exemplos expressivos da integração dos caixeiros, dos trabalhadores do comércio, na cultura urbana do Rio de Janeiro, ou da dificuldade em realizá-la.

Contudo, os maiores méritos do trabalho passam ao largo desta questão: a autora integra perfeitamente bem sua análise do passado aos temas do presente. Analisar as tensões trabalhistas dos caixeiros de tempos pregressos colabora muito para entender os conflitos dos comerciários da atualidade que, por força 
de transformações estruturais na economia, perderam seu domingo, ganho com tanta batalha após tantos anos. Afinal, não pode ser considerado menor contar a história das relações de trabalho daqueles que, na atualidade, passam ao menos um terço de suas vidas encaixotados em grandes conglomerados comerciais, respirando ar condicionado, iluminados por néon, sem ver a luz do dia e habituados a uma arquitetura feérica e orientada a um consumo que não é seu e nunca será seu.

Mostrar à sociedade a luta dos caixeiros de há mais de cem anos também expõe os valores e as mazelas de gente que já se foi há muito e que, aos poucos, parece ter vindo recolher sua moral. Camuflada de laicidade, a rejeição da folga no domingo ou sua transformação em folga semanal foi aceita pelos jovens caixeiros do presente. Por mais árduo que pareça, milhares de pessoas ainda buscam com avidez o trabalho no comércio em grandes "shoppings" onde o sol não brilha. De fato parece que a luz do dia importa menos aos comerciários de hoje que importava aos caixeiros seus antepassados.

E, contudo, o sol continua a brilhar: os patrões de outrora se transformaram em executivos ágeis e criativos, as lojas de departamentos são hoje portentosos agentes financeiros operando em todo o mundo. Os caixeiros, depois comerciários e, hoje, os que trabalham neste ramo de atividade vivem a riqueza de seu ambiente de trabalho, oposta como sempre à pobreza de sua vida real, como arranjo que lhes permite fugir da marginalidade.

Por fim, a obra de Fabiane Popinigis nos ajuda e muito a pensar o passado brasileiro como estrutura urbana, como cultura de cidade, de polis. Esse é, sem dúvida, seu maior mérito.

Recebido: maio/2009 - Aprovado: julho/2009. 
